\title{
Access to medical products, vaccines, and medical technologies
}

\section{Citation}

Marks, Stephen P. and Adriana L. Benedict. 2013. Access to Medical Products, Vaccines and Medical Technologies. In Advancing the Human Right to Health, ed. José M. Zuniga, Stephen P. Marks and Lawrence 0. Gostin, 305-324. Oxford: Oxford University Press.

\section{Published Version}

doi:10.1093/acprof:oso/9780199661619.003.0022

\section{Permanent link}

http://nrs.harvard.edu/urn-3:HUL.InstRepos:23586709

\section{Terms of Use}

This article was downloaded from Harvard University's DASH repository, and is made available under the terms and conditions applicable to Other Posted Material, as set forth at http:// nrs.harvard.edu/urn-3:HUL.InstRepos:dash.current.terms-of-use\#LAA

\section{Share Your Story}

The Harvard community has made this article openly available.

Please share how this access benefits you. Submit a story.

Accessibility 
Chapter 22

in José M. Zuniga, Stephen P. Marks and Lawrence O. Gostin (eds.), Advancing the

Human Right to Health, Oxford University Press, 2013, pp. 305-324.

\title{
Access to Medical Products, Vaccines and Medical Technologies
}

\author{
Stephen P. Marks and Adriana L. Benedict
}

\section{Introduction}

The human right to medical products, vaccines and medical technologies-which is understood here as including access to medicines, to vaccines, and to devices and procedures - is a derivative right from the right to health as well as the right to benefit from scientific progress. When the main human rights instruments were drafted, the idea that lack of access to these commodities compromised human rights was not considered, except to the extent that these were reasonable measures constituting health care. Subsequently, and particularly as a result of the AIDS pandemic, the vital need for treatment of HIV positive individuals contributed to the progressive acknowledgement that access to medicines, including antiretroviral treatments (ARTs), was an internationally recognized human right. This argument has been extended from medicines to other life-saving health goods and from HIV/AIDS to the full range of health conditions that account for the disproportionate levels of mortality and morbidity in developing countries.

Today, access to medical products, vaccines and medical technologies can be affirmed as a human right insofar as it is a significant component of two rights contained in the International Covenant on Economic, Social and Cultural Rights (ICESCR), namely, the right to health (Article 12) and the right and "to share in scientific advancement and its benefits" (Article 15(1)(b)) (UN General Assembly, 1996). The same Article 15 affirms the right "to the protection of the moral and material interests resulting from any scientific, literary or artistic production" (Article 15(1)(c)), according to which creative ideas and expressions of the human mind that possess commercial value receive the legal protection of property rights called "intellectual property (IP) rights." The major legal mechanisms for protecting IP are copyrights, patents, and trademarks, which grant owners the exclusive right to make, sell or use their original work product. There is an apparent contradiction between these two rights when applied to access to medical commodities: Article 15(1)(c) seems to protect the 'right' of companies to earn a profit from the products they develop, including by setting prices that render them inaccessible to the destitute sick, while Article 15(1)(b) seems to protect the 'right' of those destitute sick to benefit from the development of new medical products. The way out of this dilemma is to distinguish IP rights from human rights and consider them a temporary monopoly established for the valid social purpose of encouraging scientific invention and artistic creation. In other words, an IP right is a legally protected interest of a lower order than a human right, which implies a superior moral and legal claim. This distinction should not be interpreted to imply that IP rights do 
not have social value for, indeed, they have a very high value, justifying limiting Article 15 rights to promote innovation and creativity. However, as this chapter will seek to demonstrate, where the right to health is seriously impinged by IP rights, the human rights of those affected to benefit from scientific progress and to health prevails.

In order to assess the role and significance of access to medical products, vaccines and medical technologies (hereinafter referred to collectively throughout this chapter as "health technologies") in the context of the right to health, this chapter will focus on how these public health goods have been addressed in global health and in relation to the evolving definition of the right to the highest attainable standard of health, on the one hand, and in relation to protection of intellectual property and other means to promote advances in science and technology, on the other.

\section{Access to Health Goods}

While much attention has been devoted to the concept of access the medicines, and specifically to essential medicines, the broader concept used in this chapter is based on the World Health Organization's (2007a) building blocks of health systems, which include "medical products, vaccines and technologies of assured quality, safety, efficacy and cost-effectiveness". (WHO, 2007) Inclusion of this broader spectrum of goods is most compatible with the progressive realization of the right to health.

Numerous factors contribute to making health goods available in developng countries, including affordable prices; government commitment through a well-conceived and implemented national medicines policy; adequate, sustainable and equitable public sector financing; generic substitution; transparent and widely disseminated consumer information; efficient distribution; control of taxes, duties and other markups; and careful selection and monitoring (WHO, 2004). The UN Millennium Project (2005) has identified six categories of barriers to access: inadequate national commitment, inadequate human resources, failure of the international community to keep its promises to developing countries, lack of coordination of international aid, obstacles created by the World Trade Organization (WTO) Agreement on Trade-Related Aspects of Intellectual Property (TRIPS), and the failure of the current incentive structure for research and development $(\mathrm{R} \& \mathrm{D})$ to address priority health needs of developing countries (pp. 29-31). While several large international foundations (such as the Gates and Clinton Foundations) have successfully negotiated reduced prices for medicines by guaranteeing purchases and continuous demand, such strategies only address a fraction of the access gap. Similarly, donation programs, albeit commendable, fail to address the systemic challenges requiring sustainable commitments and strategies (Holt, Gillam and Ngondi, 2012).

While the literature has historically focused primarily on access to medicines, many of the considerations for access to vaccines and medical technologies are similar. As the above paragraph has, this chapter will therefore assume a degree of commonality among these categories in extrapolating lessons from access to medicines to the broader category of health goods. Nevertheless, to provide adequate context, the subcategories are briefly defined and introduced below.

\section{Medical Products (Medicines)}


The UN Development Group (2003) defines “access" in the context of medicines as "continuously available and affordable at public or private health facilities or drug outlets that are within one hour's walk of the population" (p.89). Pre-eminent among "medical products" are drugs for prevention, care or treatment which must be available to those who need them "on time, reliably, in sufficient quantity and at reasonable cost" (WHO, 2007). As stated, the historical focus on "essential medicines" is just one component of the right to health's inclusion of medical products. Because the right to the highest attainable standard of health is a progressive right, it should not be limited to those medicines formally designated as "essential" (a category which does not formally encompass many life-saving medicines due to arguably surmountable and therefore largely irrelevant cost-effectiveness and other considerations).

In 1975, half of the world's population was without access to life-saving and other essential medicines (UN Millennium Project 2005, p.4). While this proportion has decreased to about one-third of the world's population, the absolute number has remained constant at approximately two billion people (Hogerzeil and Mirza, 2011). According to WHO (2009a), public sector availability of essential medicines in 27 developing countries averages $34.9 \%$ (p. 4). The regional public sector availability of generic medicines (which are more affordable than their brand-name counterparts) is estimated to range from 29.4\% in Africa to 54.4\% in the Americas (Cameron at al. (2009) p. 5).

\section{Vaccines}

Vaccines are defined by WHO as "biological products with effects that can exceed the induction of immunological protection against specific diseases," and primarily involve preparations intended to produce immunity to a disease by stimulating the production of antibodies (WHO, 2009b). Immunization can save between two and three million lives annually in all age groups, and the principal strategy for achieving this aim is the Global Immunization Vision and Strategy (GIVS), launched in 2006 by WHO and UNICEF under the guiding principle that "[a]ll people-without distinction of race, religion, political belief, economic or social condition-have a right to equal access to the needed vaccines and interventions" (WHO and UNICEF, 2006, p.6). GIVS is a ten-year framework which aims to increase the quantity and quality of immunizations in an equitable manner, particularly in low- and middle-income countries, where, according to the World Health Assembly (WHA) (64 ${ }^{\text {th }}$ Session, 2011), "access to safe and effective vaccines is a human right that is not currently enjoyed by all people" (p.4). In order to uphold its commitment to immunization as a human right by focusing on vulnerable populations, GIVS recently shifted its emphasis from "Reaching All Districts" to "Reaching All Communities" (WHA, 64 ${ }^{\text {th }}$ Session, 2011, p.5).

A mid-term review of GIVS's progress found that although three-quarters of countries had achieved or were on track to achieve $\geq 90 \%$ coverage by 2015 for two key vaccines, DTP3 and MCV (third dose of diphtheria and tetanus toxoid with pertussis, and first dose of measles containing vaccine, respectively), nearly one-third of developing and least-developed countries were not on track, and nearly one-quarter of 68 priority countries had not made any progress (Brown, et al., 2011). Access to newer vaccines paints a similarly dismal picture: over $83 \%$ of cervical cancer cases and deaths (preventable by HPV vaccines) occur in developing countries (Erdman, 2009). 


\section{Medical Technologies}

Medical technologies encompass a wide range of devices, diagnostics and technological processes used to detect, monitor or treat medical conditions. Medical devices, in particular, have been defined to cover numerous products. Medical devices have been defined to cover numerous products ranging from simple tongue depressors and bedpans to complex programmable pacemakers with micro-chip technology and laser surgical devices" (US FDA, 2010). For purposes of regulatory control in the United States, a medical device is "an instrument, apparatus, implement, machine, contrivance, implant, in vitro reagent, or other similar or related article, including a component part, or accessory which is ... intended for use in the diagnosis of disease or other conditions, or in the cure, mitigation, treatment, or prevention of disease, in man or other animals, or intended to affect the structure or any function of the body of man or other animals, and which does not achieve any of it's primary intended purposes through chemical action within or on the body of man or other animals and which is not dependent upon being metabolized for the achievement of any of its primary intended purposes" (US Congress, 1936),

Because they often require advanced technological infrastructure, access to medical technologies is arguably even more difficult for developing countries than drugs and vaccines. For example, at least ten countries have no radiotherapy units; access to CT scanners in developing countries is less than $2 \%$ of that in high income countries; and shortages of sterilizing equipment, syringes and needles in some countries make up to $40 \%$ of all injections unsafe (WHO, 2011). Strategic Objective 11 of WHO's MediumTerm Strategic Plan 2008-2013 includes as its first aim: "Access to essential medical products and technologies, as part of the fulfillment of the right to health, recognized in countries' constitutions or national legislation" (WHO, 2008, p.87).

\section{Evolving International Human Rights Standards}

Core human rights instruments have been applied to the problem of access to health goods by UN bodies, particularly the Office of the High Commissioner for Human Rights, the Commission on Human Rights, the Special Rapporteurs on the right of everyone to the enjoyment of the highest attainable standard of physical and mental health (Special Rapporteur on the right to health), the Committee on Economic, Social and Cultural Rights (CESCR), and the Human Rights Council.

The UN Sub-Commission on the Promotion and Protection of Human Rights (2000) declared that "the implementation of the TRIPS Agreement does not adequately reflect the fundamental nature and indivisibility of all human rights, including the right of everyone to enjoy the benefits of scientific progress and its applications, the right to health..." and that "there are apparent conflicts between the intellectual property rights regime embodied in the TRIPS Agreement, on the one hand, and international human rights law, on the other" (para. 2). It also reminded "all Governments of the primacy of human rights obligations over economic policies and agreements" (para. 3) and requested that the UN High Commissioner for Human Rights prepare a report on the impact of the TRIPS Agreement on human rights, which she completed the following year (52nd Session, 2001). 
The UN Commission on Human Rights (57th Session, 2001), for its part, adopted a resolution that same year recognizing "that access to medication in the context of pandemics such as HIV/AIDS is one fundamental element for achieving progressively the full realization of the right [to health]" (para. 1). It called on states "to refrain from taking measures which would deny or limit equal access for all persons to preventive, curative or palliative pharmaceuticals or medical technologies used to treat pandemics such as HIV/AIDS or the most common opportunistic infections that accompany them" and, clearly with TRIPS in mind, "to ensure that ... the application of international agreements is supportive of public health policies which promote broad access to safe, effective and affordable preventive, curative or palliative pharmaceuticals and medical technologies" (paras. 3(a), 4(b)). The United States - which has historically pushed for "TRIPS-plus" provisions (which restrict TRIPS flexibilities intended to preserve developing countries' promotion of access to medicines (Morin, 2009)) — was the only government to abstain from this resolution.

Following numerous studies and resolutions, the UN Human Rights Council (2009) adopted resolution 12/24 in October 2009 on "access to medicines in the context of the right of everyone to the enjoyment of the highest attainable standard of physical and mental health." In the resolution, the Council not only recognized "that access to medicine is one of the fundamental elements in achieving progressively the full realization of the right of everyone to the enjoyment of the highest attainable standard of physical and mental health" (para. 1), but also encouraged "all States to apply measures and procedures for enforcing intellectual property rights in such a manner as to avoid creating barriers to the legitimate trade of medicines, and to provide for safeguards against the abuse of such measures and procedures" (para. 6), There were no objections or abstentions to this resolution.

Similarly, the CESCR (2001) issued a Statement on Human Rights and Intellectual Property, in which it considered that "intellectual property rights must be balanced with the right ... to enjoy the benefits of scientific progress and its applications," and concluded by calling for "a mechanism for a human rights review of intellectual property systems" (paras. 4, 17-18). Indeed, the CESCR (2000), in its General Comment No. 14, had interpreted the obligation under ICESCR Article 12(2)(d) ("The creation of conditions which would assure to all medical service and medical attention in the event of sickness") to include "the provision of essential drugs" (CESCR, 2000, para. 17). In clarifying the obligations of states parties, the CESCR (2000) included "essential drugs, as defined by the WHO Action Programme on Essential Drugs," among the essential facilities, goods and services, which must be available in sufficient quantity within the state (CESCR, 2000, para. 12(a)). As part of their obligation to protect, states parties have a duty "to control the marketing of medical equipment and medicines by third parties" (CESCR, 2000, para. 35), which strongly suggests that states should intervene where anti-competitive marketing of medicines and medical technologies is detrimental to the right to health. In General Comment No. 17, the CESCR (2006) challenged head-on the assumption of the international trade regime that the rights of companies holding pharmaceutical patents were of the same order as the rights of those who need the medicines, by treating the former as a temporary, revocable monopoly, and the latter as universal human rights (paras. 2 and 35). 
Both Special Rapporteurs on the right to health have actively sought to promote and further define the meaning of access to medicines from a human rights perspective. The first Special Rapporteur on the right to health, Paul Hunt, submitted a report to the UN General Assembly (2006) summarizing the responsibilities of states and of pharmaceutical companies with respect to access to medicines. Following consultation with states, NGOs, academics, pharmaceutical companies, UN agencies, national human rights institutions and other stakeholders, Hunt presented the Human Rights Guidelines for Pharmaceutical Companies in Relation to Access to Medicines (UN General Assembly, 2008), calling upon companies to: recognize the importance of human rights in their corporate mission, provide board-level responsibility and accountability for its access strategy, publicly commit to contribute to R\&D for neglected diseases, and respect the right of countries to use TRIPS flexibilities. The Guidelines also called for "an effective, transparent, accessible and independent monitoring and accountability mechanism" (UN General Assembly 2008, para. 14). Regarding patents and licensing, the Guidelines called on drug companies to "respect the right of countries to use, to the full, the provisions in ... TRIPS ..., which allow flexibility for the purpose of promoting access to medicines, including the provisions relating to compulsory licensing and parallel imports," and, more generally, to "respect the letter and spirit of the Doha Declaration" (UN General Assembly, 2008, para. 26).

The second Special Rapporteur on the right to health, Anand Grover, submitted a report to the UN Human Rights Council (11th Session, 2009) analyzing the use of TRIPS flexibilities and the adverse effect on access to medicines of "TRIPS-plus" provisions found in free trade agreements. The following year, pursuant to Council resolution $12 / 24$, quoted above, the Office of the United Nations High Commissioner for Human Rights (OHCHR) (2010) convened an expert consultation on access to medicines as a fundamental component of the right to health for an exchange of views on human rights considerations relating to the realization of access to medicines as one of the fundamental elements in achieving progressively this right, and requested the Special Rapporteur to present a summary of the discussions. In his summary, Anand Grover concluded, "While some countries lack sufficient awareness about the use of TRIPS flexibilities and have limited technical capacity to implement them, others have not streamlined their patent laws sufficiently to facilitate use of such flexibilities. Furthermore, pressure from developed countries and multinational pharmaceutical corporations have played a prominent role in shaping the implementation of TRIPS flexibilities in developing and least developed countries. For example, a number of developing countries, while attempting to implement TRIPS flexibilities to address public health concerns, have experienced pressures from developed countries and multinational pharmaceutical corporations" (UN Human Rights Council, 17th Session 2011, para. 47). He also enumerated some thirteen recommendations for governments to progressively realize access to medicines as a component of the right to health (UN Human Rights Council, 17th Session 2011, para. 49). ${ }^{1}$

\footnotetext{
1 These called for: adequate legal frameworks; proper consideration of medicine-related priorities alongside investment or industrial priorities; equality for disadvantaged minorities; universal participation in national policies and programs; regulatory systems to ensure safety and quality of medicines; national medicine supply systems tailored for vulnerable groups; monitoring and accountability mechanisms; price control
} 
Civil society consensus statements, such as the Montréal Statement on the Human Right to Essential Medicines (Pogge, 2007; Marks, 2009, pp. 94-5) and the Washington Declaration on Intellectual Property and the Public Interest (Global Congress on Intellectual Property and the Public Interest, 2011), have supported this evolution of the UN's position in this realm. Similarly, the Universities Allied for Essential Medicines (UAEM) adopted the Philadelphia Consensus Statement, stating, "We believe that access to medical care and treatment is a basic human right" (UAEM, 2006). In addition, several NGOs, such as Médecins Sans Frontières (MSF) and Oxfam, have launched campaigns on access to essential medicines (Marks, 2009, p. 93).

\section{Domestic Implementation and Litigation}

While international commitments have laid the foundations and garnered strong political will for improving access to health goods as a component of the right to health, commitments at the domestic level vary in the extent to which they render this right enforceable. Though in some cases national constitutions or their associated directive principles include specific mention of access to health goods (Kinney and Clark, 2004), in others, and indeed often in addition, access is governed by statutes translated into administrative and regulatory provisions. At this level, national health systems and essential medicines lists often define the scope of access to health technologies in the public sector (Quick, et al., 2002; Laing, Waning and Gray, 2003) (e.g., through government procurement or health insurance schemes). Medicines included on essential medicines lists are intended to be those that are required to address the population's priority health care needs, selected on the bases of disease prevalence, efficacy and safety, and cost-effectiveness (Hogerzeil, et al., 2006, p.305). However, as noted above, access to medicines as a component of the right to health calls for progressive realization of universal access to the highest attainable standard of health, including life-saving health goods excluded from public sector guarantees due to high cost.

In recent years, developing countries have adopted innovative strategies for making health goods more accessible. For instance, Mexico's health system reform has made high-cost health technologies widely accessible through its rights-based approach to catastrophic health insurance (Gomez and Frenk, chapter 14 of this volume), Brazil has strategically used TRIPS flexibilities to support its National AIDS Program (Flynn, 2011), and India has developed a generic industry so prolific that it has been called the "pharmacy of the developing world" (Waning, Diedrichsen and Moon, 2010). Indeed, the success of these national strategies relies heavily on their ability to adapt to global development and distribution frameworks (Shadlen, 2011).

In the past couple of decades, courts have increasingly played a role in expanding the scope of access to high cost health goods as a component of the right to health (chapter 2 of this book; Hogerzeil, et al., 2006; Byrne, 2009). As a result of the outcry over unaffordable drug pricing in countries confronted by the HIV/AIDS pandemic,

and dosage and efficacy standards; transparent, fair and competitive procurement practices; mechanisms to limit the impact of IP rights; guaranteed ability to use TRIPS flexibilities; technology transfer and investment in development countries; and increased effectiveness of national and international measures. 
HIV/AIDS activists began to affirm access to medicines as a right under international law (Yamin, 2003; Torres, 2002; Ferreira, 2002; Shadlen, 2007). While countless health rights cases have involved individual requests for medicines included or excluded in national essential medicines lists or public insurance schemes, group litigants have also been successful in achieving major resource re-allocations for vulnerable populations. The first major successful group claim for antiretroviral drugs (ARVs) was brought before the Constitutional Court of South Africa (2002) by the South African Treatment Action Campaign (TAC) (Berger, 2002; Patterson and London, 2002; Forman, 2008). The TAC had become South Africa's largest organization for people living with HIV, and was one of the first patient advocacy groups to build international solidarity in articulating health as a human right. Having played a critical role in incorporating health into the South African government's National Action Plan for the Protection and Promotion of Human Rights in 1998, the TAC successfully challenged the Ministry of Health's decision not to provide comprehensive ARVs for the prevention of mother-tochild transmission of HIV as a violation of the constitutionally protected right to health.

Some countries in Latin America where health is a justiciable Constitutional right have seen a recent explosion in the use of judicial remedies to achieve access to health goods (Lamprea and Andia, 2010). In Colombia - where litigation concerning access to medicines and medical technologies became so prolific that the Constitutional Court (2008) ordered a rights-based health reform - the courts have had to wrestle with the sustainability and fairness of resource-intensive judicial activism (Yamin and Parra-Vera, 2009). When courts are asked to determine what will satisfy the right to health in the absence of complete objective criteria to determine the optimal fair distribution of finite resources, their decisions have the potential to undermine democratic deliberation in administrative and legislative priority-setting. This may be especially problematic when access to courts is affected by socio-economic criteria that tend to exclude the most vulnerable populations (Ferraz and Vieira, 2008).

In some cases, when additional human rights concerns, such as nondiscrimination, have been at stake, group petitions have been heard by regional jurisdictions. Preeminent among these are the cases of $D v$. United Kingdom, decided by the European Court of Human Rights (1997), and Jorge Odir Miranda Cortez, et al. v. El Salvador, decided by the Inter-American Commission on Human Rights (2001). These supra-national rulings have significant domestic implications: Referencing these cases, a favorable decision was granted to a group of HIV patients by the Ecuador Constitutional Court (2004) in Mendoza and Ors v. Ministry of Public Health, which found that the constitutional right to health required that the Ministry of Health continue its HIV treatment program. The unprecedented success of collective HIV/AIDS medicines cases ultimately set the stage for rights-based arguments for other health technologies (Matthews, 2011). ${ }^{2}$

\footnotetext{
${ }^{2}$ However, this type of patient-advocacy litigation involving rare diseases has also had the perverse effect of providing a legal platform for corporate interests focused on expanding markets for rare disease medicines. Drug donation programs for rare diseases are increasingly used to anchor claims for government sponsorship of extremely expensive life-saving drugs that, once provided, cannot be ethically withdrawn (Heuser, 2009; Sengupta, 2012).
} 
With global implications, BRICS countries have seen a rise in litigation concerning the scope of TRIPS flexibilities (Matthews, 2011). India in particular has served as a battleground between Big Pharma and health rights advocates, not only with the upholding of its first compulsory license for a cancer drug, but also the seven-year long litigation in, regarding the Indian patent office's rejection of the patent application of Novartis, a Swiss pharmaceutical, for Gleevec (Novartis AG v. Union of India, 2013). The Supreme Court of India upheld the use of Section 3(d) of the Indian Patent Law, which uses the flexibility in TRIPS Art. 27, to limit the scope of patentable subject matter to new chemical entities, in order to curb evergreening (the filing of patents for incremental improvements in order) (Mueller, 2007). Additionally, in the few countries where they exist, patent opposition mechanisms - which provide a forum for public input regarding the validity of patent claims - can be a useful platform for health rights advocates to counter the anti-competitive effects of frivolous patent applications. To address these challenges on a broader scale, Yu (2008), George (2011), and Reiter (forthcoming 2013) have called for South-South collaboration in promoting access to generics and re-framing IP principles to promote access to health goods.

\section{Access Implications of Intellectual Property and International Trade Regimes}

Access to health goods-especially in developing countries where the vast majority of populations are uninsured or woefully underinsured - is largely determined by affordability (Maskus, 2002). While market competition promotes lower prices, IP protections encourage high prices via patents that assign drug companies monopoly rights to prevent unauthorized use (Barbosa, 2007; Attaran and Gillespie-White, 2001). As noted above, from the human rights perspective, IP rights are considered to be of a lower order than human rights, which imply a superior moral and legal claim, whereas IP rights merely establish temporary monopolies for the purpose of encouraging useful innovation (CESCR, 2006). Within developing countries, these monopolies render many health goods unaffordable - and therefore inaccessible - for most people, without necessarily serving to further incentivize innovation (Chaudhuri, 2007; Chien, 2003; Westerhaus and Castro, 2006).

IP protections are strengthened, to the detriment of access, when coupled with patent linkage and other strategies known as patent "evergreening", used to keep cheaper generic alternatives off the market (Baker, 2008; Kesselheim, 2010). "Patent linkage" refers to the way in which patents are linked to domestic regulatory and marketing approval, which is often associated with data exclusivity for the patent holder. "Data exclusivity" allows patent holders to delay generic market entry by preventing generic companies from using clinical trial and other key data for a set number of years from the date of regulatory approval, which can often exceed the life of the original patent. Other practices that are often referred to as patent "evergreening"-because they extend the length of a technology's patent protections - include: staggering patent applications (e.g., for various steps of a process, new uses, or alternate delivery methods); filing new patent applications for new mixtures or "incremental innovation" (e.g., for modifications and improvements to an existing product); infringement suits in response to generic companies' regulatory applications; and "pay for delay," in which a patent holder pays a generic company to delay market entry (Amin, 2010; Correa, 2004). In many instances, 
additional patent applications themselves can extend the life of a patent, as IP rights are often licensed so as to be circumscribed not by the term of the existing patent, but by the term during which any pending patent applications, or even appeals, remain unresolved (George, 2012).

Strong IP protections, patent linkage and patent evergreening have become increasingly insurmountable barriers to access to health goods as the international trade regime has progressively universalized the protection of these practices as the status quo (Sell, 2011; Abbott, 2006; t'Hoen, 2003). At the international level, TRIPS governs the minimum IP protections a WTO member country must enforce, requirING protection of patents for 20 years. These rights are subject to both domestic and international enforcement, and countries that fail to protect patents may be brought before the WTO's dispute settlement body by another government. Generally, access to health goods is reduced when developing countries implement TRIPS provisions relating to IP protection (Oliviera, et al., 2004; Orsi, et al., 2003).

Critically, certain TRIPS flexibilities exist to ensure that patent protections do not become barriers to access in developing countries (Sell, 2002). These flexibilities provide developing countries with the legal basis for parallel importation (importing cheaper generics from countries where relevant patents have not been filed or have expired) and compulsory licensing (manufacturing generic versions without the patent holder's authorization under certain conditions of necessity). ${ }^{3}$

In partial response to pressure brought by UN bodies and NGOs mentioned above, the fourth ministerial conference of the WTO reaffirmed TRIPS flexibilities in the Doha Declaration on the TRIPS Agreement and Public Health in November 2001. Significantly, the ministers agreed in the Doha Declaration "that the TRIPS agreement does not and should not prevent members from taking measures to ... promote access to medicines for all" (WTO, 2001, para. 4). To drive the point home, the Declaration added, "In this connection, we reaffirm the right of WTO members to use, to the full, the provisions in the TRIPS Agreement, which provide flexibility for this purpose" (WTO, 2001, para. 4), and that "[e]ach Member has the right to grant compulsory licences and the freedom to determine the grounds upon which such licences are granted" ... [and] the right to determine what constitutes a national emergency or other circumstances of extreme urgency, it being understood that public health crises, including those relating to HIV/AIDS, tuberculosis, malaria and other epidemics, can represent a national emergency or other circumstances of extreme urgency" (WTO, 2001, para. 5). The next paragraph instructed the Council for TRIPS to find an expeditious solution to the problem of compulsory licensing for countries "with insufficient or no manufacturing capacities in the pharmaceutical sector" (WTO, 2001, para. 6). This was done with the WTO (2003) General Council's authorization of "third-party compulsory licensing," allowing a manufacturer in another state to produce and export the compulsorily licensed product specifically for the benefit of the state issuing a compulsory license. The Doha

\footnotetext{
3 TRIPS Art. 31 provides: "(f) Any such use shall be authorized predominantly for the supply of the domestic market of the Member authorizing such use;" and "(h) The right holder shall be paid adequate remuneration in the circumstances of each case, taking into account the economic value of the authorization."
} 
Declaration also extended the deadline to 2016 for the least-developed countries to implement provisions (WTO, 2003).

Despite the Doha Declaration, powerful corporate and political influences discourage developing countries from taking full advantage of TRIPS flexibilities in promoting access to health goods. As early as 1998, parallel importation was challenged by 40 pharmaceutical companies (initially backed by the United States) opposed to South Africa's Medicines Act (The Pharmaceutical Manufacturer's Association and Others v. The President of the Republic of South Africa (1998)). However, the case was dropped following global public criticism of the companies' weak assertions concerning noncompliance with TRIPS (Forman, 2008; Nagan, 2002).

Similarly, compulsory licensing has been avoided on many occasions despite clearly defined need and civil society pressure (Musungu and Oh, 2006). Despite being TRIPS-compliant, the first instances of compulsory licensing of ARVs in Thailand and Brazil resulted in hostile political repercussions, such as inclusion in the US Trade Representative's "Special 301" watch list (Ford, et al., 2007) (even though the US itself has issued a number of compulsory licenses (Love, 2007)). By 2011, 17 nations-mostly upper-middle-income - had issued a total of only 24 compulsory licenses, primarily for HIV/AIDS medicines (Kuhn and Beall, 2012). When India issued its first compulsory license in 2012 for a cancer drug, effectively lowering its price by 97\% (Mukherjee, 2012), the decision was admonished by a US Patent and Trademark Office official claiming that her Office actively discouraged such practices (Rea, 2012). Nevertheless, India's first compulsory license (the second-ever license for a cancer drug) was wellreceived by many (Bhaumik and Biswas, 2012), and was soon followed by changes in Chinese patent law, and similar considerations in Brazil, to facilitate compulsory licensing (Unnikrishnan, 2012). In response, several pharmaceutical companies made commitments to slash some cancer drug prices (Whalen, 2012), and generic manufacturers made concerted efforts to target drugs "ripe" for compulsory licensing (Pilla, 2012). With compulsory licensing on the rise and increasing policy cohesion among the world's largest generic suppliers, it remains to be seen to what extent compulsory licensing can be used as a sustainable, effective legal tool safeguarded by TRIPS.

What is perfectly clear, however, is that the current global trade framework does not support access to health goods as a component of the right to health. Trade agreements and investment treaties over the past couple of decades have had clear adverse effects on affordability of health technologies in developing countries as a result of broad patent protections and associated foreign investors' rights, which, taken together, effectively block generic alternatives (Correa, 2004; Costanza, 2009; Dwyer, 2007). Hundreds of "TRIPS-plus" provisions in free trade agreements (FTAs), bilateral investment treaties/agreements (BITs/BIPAs), and other multilateral agreements (such as the proposed Trans-Pacific Partnership Agreement) seek to impose more stringent standards of IP protections for health goods than those found in TRIPS (Matthews, 2005; Fink and Reichenmiller, 2006; Castro, 2006; Flynn, et al,. 2012). These TRIPS-plus provisions include, inter alia, broader patentability standards for product claims (extending patent protection to, e.g., "incremental innovation"), additional categories of patentable products (e.g., medical procedures, which most countries exclude from 
patentability), international patent linkage, extended data exclusivity periods, narrower permissions for compulsory licensing and parallel importation, and overly broad definitions of counterfeit medicines implicating generic products (Scherer and Watal, 2002; Sell, 2007; Correa, 2006; Shukla and Sangal, 2009). Additionally, bilateral and multilateral agreements that include IP rights in their definition of protected "investments" subject domestic access-related policies-such as pharmaceutical price controls and industry regulations - to direct challenge by foreign investors via international arbitration (Rutledge, 2012).

Even in the absence of prohibitive treaty provisions, powerful corporate and political pressure-especially that surrounding ongoing negotiations-can influence governments to implement TRIPS-plus policies instead of using TRIPS flexibilities. To this end, the US has been primarily criticized for pushing TRIPS-plus provisions in FTAs (Pogge, Rimmer and Rubenstein, 2010), while the European Union has been seen as overly eager to enforce the WTO trade framework (De Bievre, 2006; Mullard, 2010). The European Parliament (2007) has responded to civil society concerns regarding TRIPS-plus provisions with a resolution calling for avoidance of such provisions in EU FTAs, but it is yet to be seen how effective this will be in practice. ${ }^{4}$

\section{Research and Development (R\&D)}

At an even more fundamental level, access to health goods depends largely on the research and development (R\&D) framework, which rewards innovations based on commercial incentives (Pécoul, et al., 1999; Grabowski, 2002). These incentives, however, disproportionately represent the buying power of high-income nations, and fail to capture the medical needs of developing countries, which not only have fewer financial resources, but are also characterized by distinct disease profiles. The Commission on Macroeconomics and Health (WHO, 2001) has usefully categorized diseases that are equally predominant in high-income and developing countries as Type I diseases, those that have a disproportionate burden in developing countries as Type II, and those that are almost exclusively found in developing countries as Type III (also referred to as "neglected tropical diseases"). While access to health goods for Type I diseases may be restricted by broad IP rights intended to promote $\mathrm{R} \& \mathrm{D}$, access to health goods for most Type II and all Type III diseases - sometimes referred to as "diseases of the bottom billion" - suffers from the additional challenge of insufficient R\&D (Røttingen, et al., 2012). Because Type II \& Type III diseases disproportionately affect poor populations and account for a greater proportion of morbidity in the developing world, they are not profitable pharmaceutical targets, and therefore require non-traditional approaches to incentivize their R\&D (Oprea, Braunack-Mayer and Gericke, 2009).

In an effort to address this innovation gap, the World Health Assembly (WHA) (2003) passed a resolution to establish the Commission on Intellectual Property Rights,

${ }^{4}$ Importantly, however, the explicit scope of this resolution was limited to "the countries of African, the Caribbean and the Pacific (ACP) and other poor developing countries and least developed countries" (par. K). 
Innovation and Public Health (CIPIH) to collect relevant and proposals from governments, academia, product development partnerships, and industry, including funding and incentives for the creation of health goods for developing countries. Following consideration of CIPIH's report, the WHA $(2006 ; 2008 ; 2009)$ established the Intergovernmental Working Group on Public Health, Innovation and Intellectual Property and adopted in 2008 the Global Strategy and Plan of Action on Public Health, Innovation, and Intellectual Property. This Global Strategy both acknowledges that intellectual property rights are "an important incentive for the development of new health-care products" and quotes the provisions of the Universal Declaration of Human Rights on sharing in scientific advances and its benefits and protection of moral and material interest resulting from scientific production (WHA, 61st Session, 2008, paras. 7 and 10). As a rare example of explicit balancing of IP rights and human rights outside of the UN human rights bodies, it is significant that among the 'principles' of the strategy, is this restatement from the preamble of the WHO Constitution: "the enjoyment of the highest attainable standard of health is one of the fundamental rights of every human being without distinction of race relation, political belief, economic or social condition" (WHA, 61st Session, 2008, para. 12).

While the Global Strategy and Plan of Action strategically prioritized goals and identified actions for governments, industry and WHO, lack of concrete targets and financing requirements has prevented its effective utilization or adoption of accountability measures. However, two consecutive working groups have fulfilled the Global Strategy's mandate to "establish a results-oriented and time-limited expert working group under the auspices of WHO and linking up with other relevant groups to examine current financing and coordination of research and development" (WHA, 2008, para.4(7)).

In 2012, the second of these, Consultative Expert Working Group on Research and Development: Financing and Coordination (CEWG), garnered international support for a "Global R\&D Convention" that would establish an evidence-based process for medical $R \& D$ priority-setting. It would also finance a dedicated $R \& D$ fund for the developing world through minor contributions from WHO member state (approimately $0.01 \%$ of GDP) and support innovative R\&D funding mechanisms, as well as establish principles aimed at ensuring access to innovation (CEWG, 2012; MSF Access Campaign, 2012; Karunakaran, 2012). Importantly, the CEWG emphasizes the importance of delinking R\&D from product prices, and experts have noted that this complex challenge will require countries to work together in determining the best options for commitment, administrative, decision-making, financial, oversight and compliance mechanisms (Røttingen, et al., 2012).

A number of alternative "push" (prior) and "pull" (ad-hoc and post-hoc) incentive mechanisms have been proposed to address the R\&D gaps inherent in the market-based innovation paradigm (Hecht, Wilson and Palriwala, 2009). "Pull" mechanisms - such as advance market commitments (e.g., donor commitments to provide incentives to vaccine makers to produce vaccines for developing countries), prize funds, and expedited regulatory review (e.g., the FDA's Priority Review Vouchers, Accelerated Approval, and Fast-Track regulatory review) — reward R\&D outcomes by facilitating commercialization of valuable but less profitable health products (Towse and Kettler, 2005; Love and 
Hubbard, 2007; Robertson, et al., 2012). Several "pull" mechanism proposals have yet to be tested. For instance, "pay-for-performance" patents, such as those contemplated by the proposed Health Impact Fund, would use government and donor financing to reimburse patent holders on the basis of health impact in lieu of normal profits gained from market exclusivity (Hollis and Pogge, 2008; Banerjee, Hollis and Pogge, 2010). Other proposals include patent buy-outs (Outterson, 2006), transferable IP rights and market exclusivity (Spellburg, et al., 2008), and reduction of patent length (Center for Global Health R\&D Policy Assessment, 2012).

"Push" mechanisms, on the other hand, incentivize earlier stages of product development. Patent pools, for instance, bring patents into a collectively owned and managed pool that can issue voluntary licenses to generic companies for product development (Choi 2003). The UNITAID Medicines Patent Pool (MPP), which is funded by a tax on airline ticket sales, has pooled patents to facilitate voluntary licensing of four chemical entities which, when combined, are a powerful fixed-dose anti-retroviral combination (UNITAID, 2011). ${ }^{5}$ More recently, WIPO's Re:Search initiative, a royaltyfree patent pool for neglected tropical disease $R \& D$, has resulted in its first agreement between universities and pharmaceutical companies to research new treatments for Chagas disease, sleeping sickness, schistosomiasis, and tuberculosis (WIPO, 2012).

Other "push" mechanisms that have seen some success include targeted diseasespecific funding (Blume-Kohout, 2012), health innovation networks for developing countries (Morel, et al., 2005), capacity-building and technology transfer initiatives (Friede, et al., 2009), open-source and crowd-sourced R\&D for neglected diseases (Munos, 2010; Maurer, Rai and Sali, 2004; Årdal and Røttingen, 2012) and privatepublic product development partnerships (Frost and Reich, 2008; Nwaka and Ridley, 2003). "Push" mechanisms that have been proposed but not yet tested include taxes on patents (Beall and Kuhn, 2012); and making undisclosed clinical trial data an international public good (Reichman, 2006). Similarly, innovative financial models that de-link R\&D incentives from profits include: cost sharing for clinical trials (Lewis, Reichman and So, 2007), an International Finance Facility for Immunization (IFFIm, 2012), neglected disease and global health tax credits (Rao, 2011), additional fees on patent applications called "Green IP" (Nitta, 2006), and selling expedited regulatory review vouchers to raise money for neglected disease R\&D (Moran, 2005) (Center for Global Health R\&D Policy Assessment, 2012).

While it is of the utmost importance, de-linking R\&D from prices is just the first step in promoting access to health goods. Regardless of the R\&D mechanism, health innovations need to be licensed responsibly to ensure that publicly funded research benefits global health in an equitable way. To this end, global access licensing incorporates into health technology licenses terms such as agreements not to enforce patents in developing countries, march-in rights for public institutions, and tiered royalties. The Access to Medicines Index ranks pharmaceutical companies based on their

\footnotetext{
${ }^{5}$ While the MPP is expected to speed availability of a new fixed-dose, single tablet ARV regimen in countries included in the patent pool, the MPP has been criticized by several health rights advocates in the "Global South" for, inter alia, excluding key developing countries and legitimizing questionable voluntary licensing practices that delay generic market entry (George, 2012).
} 
efforts, including through responsible licensing, to increase access to medicines; a proposed Access to Medical Devices Index may enhance these efforts (ATMI, 2012). Global access licensing has increasingly been used by academic institutions to ensure that health-related innovations - especially diagnostics and medical devices, which are commonly developed in academia-reach the global poor (Chokshi, 2006). The Universities Allied for Essential Medicines (UAEM, 2006), mentioned above, has been a key player in promoting global access licensing alongside neglected disease research, including through efforts to monitor implementation of the multi-institution Statement of Principles and Strategies for the Equitable Dissemination of Medical Technologies (AUTM, 2009).

\section{Conclusion}

This chapter has reviewed the evolving international human rights standards that relate to access to medicines, vaccines and medical technologies, and identified the gap between the commitment in principle to enhancing this access as part of the right to health and the right to benefit from scientific progress, on the one hand, and the obstacles posed by the intellectual property and international trade regimes, on the other. The sheer breadth and complexity of the legal, economic, political, ethical and technical considerations surrounding universal access to health goods cannot be properly addressed in one chapter. We noted progress in domestic implementation and increased use of judicial remedies in achieving access to life-saving health goods. Other strategies include increasing generic manufacturing capacities in developing countries, public health insurance schemes, and strengthening supply-chain infrastructure. (Hollis and Pogge, 2008; Rovira, 2006; Kaplan and Lang, 2005).

The trend in access to health goods, particularly in developing countries, provides the evidence for policies in global heath to increase access at all stages of the process, from setting research priorities for the development of new drugs, to manufacturing, pricing, marketing, and distribution. Critical challenges remain. While the international trade regime has to some extent adjusted to the political imperative of promoting development and strategies defined by the international financial institutions in poverty reduction programs and the UN system in the MDGs, it has not, so far, been receptive to the claim that access to health goods is guaranteed by a human right to health and the right to benefit from scientific progress. Similarly, the medical R\&D system has not yet adapted to the global imperatives of these human rights calling for both availability and affordability of medical products. The developments described in this chapter are signs that the human right to medical products, vaccines and medical technologies has advanced in terms of its normative content and its legal recognition. Nevertheless, it remains a daunting challenge to bridge remaining gaps in political will to effectively mobilize adequate resources to ensure reliable and sustainable implementation and accountability frameworks, create accommodation with the international trade regime and find incentives for innovation and affordable pricing.

\section{BIBLIOGRAPHY}


Abbott, F.M., 2006, The cycle of action and reaction: Developments and trends in intellectual property and health. In: P. Roffe, G. Tansey, and D.V. Eugui, eds., Negotiating health: intellectual property and access to medicines, Earthscan: London. p.27.

Access to Medicine Index, 2012. Access to medicine index. [online] Available at: http://www.accesstomedicineindex.org/. [Accessed on 10 October 2012.]

Amin, T., 2010. Re-visiting the patents and access to medicines dichotomy: An evaluation of TRIPS implementation and public health safeguards in developing countries. In: O. Aginam, J. Harrington, and P. Yu, eds., Global governance of HIV/AIDS: Intellectual property and access to essential medicines. Northampton: Edward Elgar Publishing Ltd. Ch. 6.

Årdal, C., and Røttingen, J.-A., 2012. Open source drug discovery in practice: A case study. PLOS Neglected Tropical Diseases, 6(9), p.e1827.

Attaran, A., and Gillespie-White, L., 2001. Do Patents for Antiretroviral Drugs Constrain Access to AIDS Treatment in Africa? Journal of the American Medical Association, 286(15), pp.1886-92.

AUTM, 2009. Statement of principles and strategies for the equitable dissemination of medical technologies. [online] Available at:

https://www.autm.net/Content/NavigationMenu/TechTransfer/GlobalHealth/statementofp rincliples.pdf. [Accessed on 10 October 2012.]

Baker, B.K., 2008. Ending drug registration apartheid: Taming data exclusivity and patent/registration linkage. American Journal of Law and Medicine, 34(2-3), pp.303-44.

Banerjee, A., Hollis, A., and Pogge, T., 2010. The Health Impact Fund: Incentives for improving access to medicines. The Lancet, 375(9709), pp.166-9.

Barbosa, D.B., 2007. Why intellectual property may create competition problems. [online] Available at: SSRN, http://papers.ssrn.com/sol3/papers.cfm?abstract id=1006085. [Accessed on 20 September 2010.]

Beall, R., and Kuhn, R., 2012. Trends in compulsory licensing of pharmaceuticals since the Doha Declaration: A database analysis. PLOS Medicine, 9(1), p. e1001154.

Berger, J.M., 2002. Litigation strategies to gain access to treatment for HIV/AIDS: The case of South Africa's Treatment Action Campaign. Wisconsin International Law Journal 20, pp.597-609.

Bhaumik, S., and Biswas, T., 2012. From outlier to trendsetter. Canadian Medical Association Journal, 184(12), pp.E635-6. 
Blume-Kohout, M.E., Does targeted, disease-specific public research funding influence pharmaceutical innovation? Journal of Policy Analysis and Management, 31(3), pp.64160.

Brown, D.W., Burton, A., Gacic-Dobo, M., Karimov, R.I., Vandelaer, J., and OkwoBele, J.M., 2011. A mid-term assessment of progress towards the immunization coverage goal of the Global Immunization Vision and Strategy (GIVS). BMC Public Health, 11, p. 806.

Cameron, A., Ewen, M., Ross-Degnan, D., Ball, D., and Laing, R., 2009. Medicine prices, availability, and affordability in 36 developing and middle-income countries: a secondary analysis. The Lancet, 373(9659), p.632.

Castro, R., 2006. Intellectual Property Rights in Bilateral Investment Treaties and Access to Medicines: The Case of Latin America. Journal of World Intellectual Property, 9(5), pp.548-72.

Choi, J.P., 2003. Patent pools and cross-licensing in the shadow of patent litigation. CESifo Working Paper, 1070. Available at SSRN: http://papers.ssrn.com/sol3/papers.cfm?abstract id=466062. [Accessed on 20 September 2012.]

Chokshi, D.A., 2006. Improving access to medicines in poor countries: The role of universities. PLOS Medicine, 3(6), p. e136.

Center for Global Health R\&D Policy Assessment, 2012. Policy Innovations. Results for Development Institute. [online] Available at: http://healthresearchpolicy.org/innovation. [Accessed on 20 September 2012.]

CESCR, 2000. General Comment No. 14 on the right to the highest attainable standard of health, 11 August 2000, UN Doc. E/C.12/2000/4.

CESCR, 2001. Human Rights and Intellectual Property: Statement by the Committee on Economic Social and Cultural Rights, UN Doc. E/C.12/2001/15, 14 December 2001.

CESCR, 2006. General Comment No. 17 on the right of everyone to benefit from the protection of the moral and material interests resulting from any scientific, literary or artistic production of which he or she is the author, $\mathrm{UN}$ doc. $\mathrm{E} / \mathrm{C} .12 / \mathrm{GC} / 17$.

Chaudhuri, S., 2007. Is product patent protection necessary in developing countries for innovation?: R\&D by Indian pharmaceutical companies after TRIPS. Working Paper Series, 614, Indian Institute of Management, Calcutta, September.

Chien, C., 2003. Cheap drugs at what price to innovation: Does the compulsory licensing of pharmaceuticals hurt innovation? Berkeley Technology Law Journal, 18(1), pp.1-57. 
CEWG, 2012. Research and development to meet the needs of developing countries: Strengthening global financing and coordination. Geneva: WHO.

Constitutional Court of Colombia, 2008. Sentencia T-760. Sala Segunda de Revisión, 31 Jul.

Constitutional Court of Ecuador, 2004. Mendoza and Ors v. Ministry of Public Health and the Director of the National AIDS-HIV-STI Program. Tribunal Constitucional, 3ra. Sala. Resolucion No. 0749-2003-RA.

Constitutional Court of South Africa, 2002. Minister of Health v. Treatment Action Campaign. 5 SA 721.

Correa, C.M., 2004. Bilateralism in intellectual property: Defeating the WTO system for access to medicines. Case Western Reserve Journal of International Law, 36, p.79.

Correa, C.M., 2006. Implications of bilateral free trade agreements on access to medicines, Bulletin of the World Health Organization, 84(5), pp.399-404.

Costanza, L., 2009. The security of international investments: A synthesis of impacts on public policies and domestic law in host states. LLM Dissertation (Laws 592), Faculty of Law, Victoria University of Wellington. [online] Available at:

http://researcharchive.vuw.ac.nz/bitstream/handle/10063/1145/thesis.pdf? sequence=1. [Accessed on 20 September 2012.]

De Bievre, D., 2006. The EU regulatory trade agenda and the quest for WTO enforcement. Journal of European Public Policy, 13(6), pp.851-66.

Drahos, P., 2007. Four lessons for developing countries from the trade negotiations over access to medicines. Liverpool Law Review, 28(1), pp. 11-39.

Dwyer, L., 2007. Patent protection and access to medicine: The Colombian and Peruvian Trade Promotion Agreements. Law and Business Review, 13, p.825.

Erdman, J.N., 2009. Human rights in health equity: cervical cancer and HPV vaccines. American Journal of Law and Medicine, 35(2-3), pp.365-87.

European Court of Human Rights, 1997. D v. United Kingdom. Case No. 146/1996/767/964.

European Parliament, 2007. Resolution of 12 July 2007 on the TRIPS agreement and access to medicines. Text adopted: P6_TA(2007)0353.

Ferraz, O.M., and Vieira, F., 2008. Direito à Saúde, Recursos Escassos e Equidade: Os Riscos da Interpretação Judicial Dominante. Revista de Ciências Sociais, 52(1), pp.223-51. 
Ferreira, L., 2002. The human rights obligations of multinational pharmaceutical corporations. Fordham Law Review, 71(3), pp.1133-79.

Fink, C., and Reichenmiller, P., 2006. Tightening TRIPS: Intellectual property provisions of U.S. free trade agreements. In: R. Newfarmer, ed., Trade, Doha, and development: A window into the issues. Washington, D.C.: World Bank. Ch. 24.

Flynn, M., 2011. Corporate power and state resistance: Brazil's use of TRIPS flexibilities for its National AIDS Program. In: K.C. Shadlen, ed., Intellectual property, pharmaceuticals and public health: Access to drugs in developing countries. Northampton: Edward Elgar Publishing, Inc. Ch. 6.

Flynn, S.M., Kaminski, M.E., Baker, B.K., and Koo, J.H., 2011. Public interest analysis of the US TPP proposal for an IP chapter. PIJIP Research Paper Series, 21. [online] Available at: http://digitalcommons.wcl.american.edu/cgi/viewcontent.cgi?article=1023\&context=rese arch. [Accessed on 20 September 2012.]

Ford, N., Wilson, D., Costa Chavez, G., Lotrowska, M., and Kijtiwatchakul, K., 2007. Sustaining access to antiretroviral therapies in the less-developed world: Lessons from Brazil and Thailand. AIDS, 21(Supp. 4), pp.S21-9.

Forman, L., 2008. 'Rights' and wrongs: What utility for the right to health in reforming trade rules on medicines? Health and Human Rights: An International Journal, 10(2), pp.37-52.

Friede, M., Palkonyay, L., Alfonso, C., Pervikov, Y., Torelli, G., Wood, D., and Kieny, M.P., 2011. WHO initiative to increase global and equitable access to influenza vaccine in the event of a pandemic: Supporting developing country production capacity through technology transfer. Vaccine, 29(Supp. 1), pp.A2-A7.

Frost, L.J., and Reich, M., 2008. Access: How do good health technologies get to poor people in poor countries? Cambridge: Harvard Center for Population and International Health.

George, E., 2011. South Africa and South-South cooperation to reframe global intellectual property principles and promote access to essential medicines. Indiana Journal of Global Legal Studies 18(1) pp.167-97.

George, J., 2012. Patent pool: Legitimising big pharma's practices? Access, 3(1). [online] Available at: http://www.lawyerscollective.org/files/Access\%20\%20Vol\%20III,\%20No \%201.pdf. [Accessed on 20 September 2012.]

Grabowski, H., 2002. Patents, innovation and access to new pharmaceuticals. Journal of International Economic Law, 5(4), pp.849-60. 
Heuser, S., 2009. One Girl's Hope, a Nation's Dilemma. Boston Globe, 14 June.

Hogerzeil, H.V. and Mirza, Z., 2011. The world medicines situation 2011: Access to essential medicines as part of the right to health. Geneva: WHO.

Hecht, R., Wilson, P., and Palriwala, A., 2009. Improving health R\&D financing for developing countries: A menu of innovative policy options. Health Affairs, 28(4), pp.974-85.

Global Congress on Intellectual Property and the Public Interest, 2011. Washington Declaration on Intellectual Property and the Public Interest. Adopted 27 August at Washington College of Law, Washington, D.C.

Hogerzeil, H.V., Samson, M., Casanovas, J.V., and Rahmani-Ocora, L., 2006. Is access to essential medicines as part of the fulfillment of the right to health enforceable through the courts? The Lancet, 368(9532), pp.305-11.

IFFIm, 2012. IFFIm: Supporting GAVI. [online] Available at: http://www.iffim.org/index.aspx. [Accessed on 10 October 2012.]

Hollis, A. and Pogge, T. The Health Impact Fund: Making New Medicines Accessible for All . Incentives for Global Health, 2008.

Holt, F., Gillam, S.J., Ngondi, J.M., 2012. Improving access to medicines for neglected tropical diseases in developing countries: Lessons from three emerging economies. PLOS Neglected Tropical Disease, 6(2), p.e1390.

Tim Hubbard and James Love, "A New Trade Framework for Global Healthcare R\&D," PLOS Biology 2:2 (2004).

Inter-American Commission on Human Rights, 2001. Jorge Odir Miranda Cortez et al. v. El Salvador. Case 12.249, Report No. 27/09.

Kaplan, W.A., and R. Laing, 2005. Local Production: Industrial Policy and Access to Medicines. Health, Nutrition and Population Discussion Paper. Geneva, World Bank.

Karunakaran, K., 2012. Why India needs to back a new R\&D treaty in health sector. The Economic Times. 5 Jul. [online] Available at:

http://articles.economictimes.indiatimes.com/2012-07-05/news/32551747_1 treaty-r-dindian-firms. [Accessed on 10 October 2012.]

Kesselheim, A.S., 2008. Think globally, prescribe locally: how rational pharmaceutical policy in the US can improve global access to essential medicines. American Journal of Law and Medicine, 34(2-3), pp.125-39.

Kinney, E.D., and Clark, B.A., 2004. Provisions for health and health care in the constitutions of the countries of the world. Cornell International Law Journal, 37, p.285. 
Kuhn, R., and Beall, R.F., 2012. The time for pharmaceutical compulsory licensing has expired. Nature Medicine.

Laing, R., Waning, B., and Gray, A., 2003. 25 Years of the WHO Essential Medicines Lists: Progress and Challenges. The Lancet, 361(9370), pp.1723-9.

Lamprea, E., and Andia, T., 2010. Local Maladies, Global Remedies: Rethinking Right to Health Duties. Global Justice, Stanford University. [online] Available at: http://iisdb.stanford.edu/evnts/6170/Global_Justice_May_21_2010.pdf. [Accessed 20 September 2012].

Lewis, T.R., Reichman, J.H., and So, A.D., 2007. The case for public funding and public oversight of clinical trials. The Economists' Voice, 4(1).

Love, J., 2007. Recent examples of the use of compulsory license on patents. Washington, D.C.: Knowledge Ecology International. [online] Available at:

http://www.keionline.org/misc-docs/recent_cls_8mar07.pdf. [Accessed on 20 September 2012.]

Love, J., and Hubbard, T., 2007. The big idea: Prizes to stimulate R\&D for new medicines. Chicago-Kent Law Review, 82(3), pp.1519-54.

Marks, S.P., 2009. Access to Essential Medicines as a component of the right to health, in Andrew Clapham and Mary Robinson (eds.), Realizing the Right to Health, Zurich, Switzerland: Rüfer \& Rub, the Swiss Human Rights Book Series, 2009, pp. 82-101.

Maskus, K.E., 2002. Ensuring Access to Essential Medicines: Some Economic Considerations. Wisconsin International Law Journal, 20(2), pp.563-79.

Matthews, D.N., 2005. TRIPS flexibilities and access to medicines in developing countries: The problem with technical assistance and free trade agreements. European Intellectual Property Review, 27, pp.420-7.

Matthews, D., 2011. When framing meets law: Using human rights as a practical instrument to facilitate access to medicines in developing countries. The WIPO Journal, 3(1), pp.113-27.

Maurer, S.M., Rai, A., and Sali, A., 2004. Finding cures for tropical disease: Is open source an answer? PLOS Medicine, 1(3), p.e56.

Moran, M., 2005. Fast track options as a fundraising mechanism to support R\&D into neglected diseases. Pharmaceutical R\&D Policy Project, London School of Economics. Jan. [online] Available at: 
http://www.who.int/intellectualproperty/submissions/Mary.Moran2.pdf. [Accessed on 10 October 2012.]

Morel, C.M., Acharya, T., Broun, D., Dangi, A., Elias, C., Ganguly, N.K., Gardner, C.A., Gupta, R.K., Haycock, J., Heher, A.D., Hotez, P.J., Kettler, H.E., Keusch, G.T., Krattiger, A.F., Kreutz, F.T., Lall, S., Lee, K., Mahoney, R., Martinez-Palomo, A., Mashelkar, R.A., Matlin, S.A., Mzimba, M., Oehler, J., Ridley, R.G., Senanayake, P., Singer, P., Yun, M., 2005. Health innovation networks to help developing countries address neglected diseases. Science, 309, pp.401-3.

Morin, J.-F, 2009. Multilateralizing TRIPs-plus agreements: Is the US strategy a failure? Journal of World Intellectual Property, 12, pp.175-97.

MSF Access Campaign, 2012. How a global R\&D convention could fill the gaps left by today's medical innovation system. New York: MSF. [online] Available at: http://www.msfaccess.org/sites/default/files/MSF assets/Innovation/Docs/MedInno Brie fing GlobalConventionRD ENG_2012Update.pdf. [Accessed on 10 October 2012.]

Mueller, J.M., 2007. Taking TRIPS to India - Novartis, patent law and access to medicines. The New England Journal of Medicine, 356, pp.541-3.

Mukherjee, R., 2012. Big pharma lobbies hard to curb generics. Times of India, 16 Aug. [online] Available at:

https://mail.google.com/mail/?voice\&shva=1\#search/mukherjee/1392eff773ab914e.

[Accessed on 20 September 2012.]

Mullard, A., EU implicated in controversial counterfeiting bill. The Lancet, 375(9723), p.1335.

Munos, B., 2010. Can open-source drug R\&D repower pharmaceutical innovation? Nature Reviews Drug Discovery, 5, pp.723-9.

Musungu, S.F., and Oh, C., 2006. The use of flexibilities in TRIPS by developing countries: Can they promote access to medicines? Geneva: WHO - South Centre.

Nagan, W.P., 2002. International intellectual property, access to health care, and human rights: South Africa v. United States. Florida Journal of International Law, 14, p.155.

Nitta, I., 2006. Patent insurance (green intellectual property) scheme: A financial prescription for neglected diseases? [online] Available at: http://www.who.int/phi/GreenIP.pdf. [Accessed on 10 October 2012.]

Nwaka, S., and Ridley, R.G., 2003. Virtual drug discovery and development for neglected diseases through public-private partnerships. Nature Reviews Drug Discovery, 2, pp.919-28. 
Oliveira, M.A., Zepeda Bermudez, J.A., Costa Chavez, G., and Velasquez, G., 2004. Has the implementation of the TRIPS agreement in Latin America and the Caribbean produced intellectual property legislation that favours public health? Bulletin of the World Health Organization, 82(11), pp.815-21.

Oprea, L., Braunack-Mayer, A., and Gericke, C.A., 2009. Ethical issues in funding research and development of drugs for neglected tropical diseases. Journal of Medical Ethics, 35, pp.310-4.

Orsi, F., Hasenclever, L., Fialho, B., Tigre, P., and Coriat, B., 2003. Intellectual property rights, anti-AIDS policy and generic drugs: Lessons from the Brazilian Public Health Program. In: J.-P. Moatti et al., eds., Economics of AIDS and access to HIV/AIDS care in developing countries: Issues and challenges. Le Publier: Paris, pp.109-34.

Outterson, K., 2006. Innovations for low- and middle-income countries. American Journal of Law and Medicine, 32, pp.159-73.

Patterson, D., and London, L. International law, human rights and HIV/AIDS. Bulletin of the World Health Organization, 80(12), pp.964-9.

Pécoul, B., Chirac, P., Trouiller, P., and Jacques, P., 1999. Access to essential drugs in poor countries: A lost battle? Journal of the American Medical Association, 281(4), pp.361-7.

The Pharmaceutical Manufacturer's Association and Others $v$. The President of the Republic of South Africa. Case no. 4183/98, Trans. Prov. Div., South Africa.

Pilla, V., 2012. Natco targets drugs ripe for compulsory licensing. Livemint \& The Wall Street Journal, 19 Jul. [online] Available at: http://www.livemint.com/Companies/ZR7YHsT0xTb6e9ppKDIAuN/Natco-targetsdrugs-ripe-for-compulsory-licensing.html. [Accessed on: 20 September 2012.]

Pogge, T., 2007. Montréal Statement on the Human Right to Essential Medicines. Cambridge Quarterly of Healthcare Ethics, 16(1), pp.104-8.

Pogge, T., Rimmer, M., and Rubenstein, K., 2010. Incentives for global public health: Patent law and access to essential medicines. Cambridge: Cambridge University Press.

Quick, J.D., Hogerzeil, H.V., Velásquez, G., and Lembit, R., 2002. Twenty-Five Years of Essential Medicines. Bulletin of the World Health Organization, 80(11), pp.913-14.

Rao, A., 2011. Can a R\&D tax credit expand investment in product development for global health? Results for Development Institute, 28 Feb. [online] Available at: http://healthresearchpolicy.org/sites/healthresearchpolicy.org/files/assessments/files/Tax $\% 20$ Credit $\% 20$ Draft $\% 20$ Consultation\%20Draft $\% 202 \% 2028$.pdf. [Accessed on 10 October 2012.] 
Rea, T.S., 2012. USPTO on the Hill: Supporting U.S. innovators in global markets. Director's Forum: David Kappos' Public Blog, uspto.gov. 2 Jul. [online] Available at: http://www.uspto.gov/blog/director/entry/uspto on the hill supporting. [Accessed on 20 September 2012.]

Reichman, J.H., 2006. The international legal status of undisclosed clinical trial data: From private to public goods? In: P. Roffe, G. Tansey, and D.V. Eugui, eds., Negotiating health: Intellectual property and access to medicines. Earthscan: London. p.133.

Bernd Reiter, forthcoming 2013. Overcoming coloniality: The potential of South-South Dialogue about citizenship, participatory democracy, and development between Brazil and India, in Aparajita Gangopadhyay (ed.), India Brazil Dialogue. Cambridge: Cambridge University Press.

Roderick, P., and Pollock, A.M., 2012. India's patent laws under pressure. The Lancet, 380(9846), pp.e2-4.

Rovira, J., 2006. Creating and Promoting Domestic Drug Manufacturing Capacities: A Solution for Developing Countries? In: P. Roffe, G. Tansey, and D.V. Eugui, eds., Negotiating health: Intellectual property and access to medicines. London: Earthscan. Ch. 12.

Robertson, A.S., Stefanakis, R., Joseph, D., and Moree, M., 2012. The impact of the US Priority Review Voucher on private-sector investment in global health research and development. PLOS Neglected Tropical Diseases, 6(8), p.e1750.

Røttingen, J.-A., Chamas, C., Goyal, L.C., Harb, H., Lagrada, L., and Mayosi, B.M., 2012. Securing the public good of health research and development for developing countries. Bulletin of the World Health Organization, 90(5), pp.398-400.

Rutledge, P.B., 2012. TRIPS and BITS: An essay on compulsory licenses, expropriation, and international arbitration. North Carolina Journal of Law \& Technology, 13, p.149 (2012).

Scherer, F.M., and Watal, J., 2002. Post-TRIPS options for access to patented medicines in developing nations. Journal of International Economic Law, 5(4), pp.913-39.

Sell, S.K., 2002. TRIPS and the Access to Medicines Campaign. Wisconsin International Law Journal, 20, p.481.

Sell, S.K., 2007. TRIPS-plus free trade agreements and access to medicines. Liverpool Law Review, 28(1), pp.41-75.

Sell, S.K., 2011. TRIPS was never enough: Vertical forum shifting, FTAs, ACTA, and TPP. Journal of Intellectual Property Law, 18, p.447. 
Sengupta, A., 2012. Patent to plunder. Frontline, 29(8). [online] Available at: http://www.frontlineonnet.com/fl2908/stories/20120504290800400.htm. [Accessed on 20 September 2012.]

Shadlen, K.C., 2007. The political economy of AIDS treatment: Intellectual property and the transformation of generic supply. International Studies Quarterly, 51(3), pp.559-81.

Shadlen, K.C., 2011. The politics of patents and drugs in Brazil and Mexico: The industrial bases of health policies. In: K.C. Shadlen, ed., Intellectual property, pharmaceuticals and public health: Access to drugs in developing countries. Northampton: Edward Elgar Publishing, Inc. Ch. 7.

Shukla, N., and Sangal, T., 2009. Generic drug industry in India: The counterfeit spin. Journal of Intellectual Property Rights, 14(3), pp.236-40.

Spellburg, B., Guidos, R., Gilbert, D., Bradley, J., Boucher, H.W., Scheld, W.M., Bartlett, J.G., Edwards, J., Jr., and the Infectious Diseases Society of America. The epidemic of antibiotic-resistant infections: A call to action for the medical community from the Infectious Diseases Society of America. Clinical Infectious Diseases, 46(2), pp.155-64.

Supreme Court of India, Novartis AG v. Union of India (UOI) and Ors.; Natco Pharma Ltd. v. UoI \& Ors.; M/S Cancer Patients Aid Association v. UoI \& Ors. Civil Appeal No. 2706-2716 of 2013.

t'Hoen, E., 2003. TRIPS, Pharmaceutical Patents and Access to Essential Medicines: Seattle, Doha and Beyond. In: J.-P. Moatti, Barnett, T., Coriat, B., and Souteyrand, Y., Dumoulin, J., and Flori, Y.-A., eds., Economics of AIDS and Access to HIV/AIDS Care in Developing Countries: Issues and Challenges. Paris: Le Publier.

Torres, M.A., 2002. The human right to health, national courts, and access to HIV/AIDS treatment: a case study from Venezuela. Chicago Journal of International Law, 3, p.105.

Towse, A., and Kettler, H., 2005. Advance price or purchase commitments to create markets for treatments for diseases of poverty: Lessons from three policies. Bulletin of the World Health Organization, 83(4), pp. 301-7.

UN Commission on Human Rights, $57^{\text {th }}$ Session, 2001. Resolution 2001/33, Access to medication in the context of pandemics such as HIV/AIDS, UN Doc.

E/CN.4/RES/2001/33.

UN Development Group, 2003. Indicators for monitoring the Millennium Development Goals. New York: UN. 
UN General Assembly, 1996. International Covenant on Economic, Social and Cultural Rights, UNTS 993/3.

UN General Assembly, 2006. Report of the Special Rapporteur on the right or everyone to the highest attainable standard of physical and mental health, Paul Hunt. UN Doc. A/61/338.

UN General Assembly, 2008. Report of the Special Rapporteur on the right or everyone to the highest attainable standard of physical and mental health, Paul Hunt. UN Doc. A/63/263.

UN Human Rights Council, $11^{\text {th }}$ Session, 2009. Report of the Special Rapporteur on the right of everyone to the highest attainable standard of physical and mental health, Anand Grover. UN Doc A/HRC/11/12.

UN Human Rights Council, 17 ${ }^{\text {th }}$ Session, 2011. Report of the Special Rapporteur on the right of everyone to the highest attainable standard of physical and mental health, Anand Grover: Expert consultation on access to medicines as a fundamental component of the right to health. UN Doc A/HRC/17/43.

UN Millennium Project, Task Force on HIV/AIDS, Malaria, TB and Access to Medicines, Working Group on Essential Medicines, 2005. Prescription for healthy development: Increasing access to medicines. London: Earthscan.

UN Sub-Commission on the Promotion and Protection of Human Rights, $51^{\text {st }}$ Session, 2000. Intellectual property rights and human rights. UN Doc. E/CN.4/RES/2000/7.

UN Sub-Commission on the Promotion and Protection of Human Rights, $52^{\text {nd }}$ Session, 2001. The impact of the Agreement on Trade-Related Aspects of Intellectual Property Rights on human rights: Report of the High Commissioner. UN Doc.

E/CN.4/Sub.2/2001/13.

UNAIDS, 2006. Courting rights: Case studies in litigating the human rights of people living with HIV. Geneva: UNAIDS.

UNITAID, 2012. Medicines Patent Pool. [online] Available at http://www.medicinespatentpool.org/. [Accessed on 20 September 2012.]

Unnikrishnan, C.H., 2012. Big pharma firms may learn to live with compulsory licensing. The Livemint \& The Wall Street Journal, 21 Jun. [online] Available at: http://www.livemint.com/2012/06/21214055/Big-pharma-firms-may-learn-to.html. [Accessed on 20 September 2012.]

US Congress (1936), Federal Food, Drug and Cosmetic Act, 21 U.S.C. $§ 321(\mathrm{~h})$.

US FDA 2010, US Department of Health and Human Services, Food and Drug Administration, Medical Devices, 1 March. [online]. Available at: 
http://www.fda.gov/medicaldevices/deviceregulationandguidance/overview/classifyyourd evice/ucm051512.htm. [Access on October 22, 2012.]

Waning, B., Diedrichsen, E., and Moon, S., 2010. A lifeline to treatment: The role of Indian generic manufacturers in supplying antiretroviral medicines to developing countries. Journal of the International AIDS Society, 13, p.35.

Westerhaus, M., and Castro, A., 2006. How do intellectual property law and international trade agreements affect access to antiretroviral therapy? PLOS Medicine, 3(8), pp.1230-6.

Whalen, J., 2012. Cancer drugs get cheaper, in India. Wall Street Journal, 23 March. [online] Available at:

http://online.wsj.com/article/SB10001424052702303812904577297673910205972.html. [Accessed on 20 September 2012.]

WHA, 56 ${ }^{\text {th }}$ Session, 2003. Resolution WHA56.27 - Intellectual property rights, innovation and public health. WHA56/27.

WHA, 59 ${ }^{\text {th }}$ Session, 2006. Resolution 59.24 - Public health, innovation, essential health research and intellectual property rights: Towards a global strategy and plan of action. WHA59/24.

WHA, $61^{\text {st }}$ Session, 2008. Resolution 61.21 - Global strategy and plan of action on public health, innovation and intellectual property. WHA61/21.

WHA, $62^{\text {nd }}$ Session, 2009. Resolution 62.16 - Global strategy and plan of action on public health, innovation and intellectual property. WHA62/16.

WHA, $64^{\text {th }}$ Session, 2011. Global Immunization Vision and Strategy: Progress report and strategic direction for the Decade of Vaccines. WHA64/14.

WHO, 2001, Commission on Macroeconomics and Health, 2001. Macroeconomics and health: Investing in health for economic development. Geneva: WHO.

WHO, 2004. WHO Medicines Strategy 2004-2007: Countries at the core. Geneva: WHO.

WHO, 2007. Everybody's business: Strengthening health systems to improve health outcomes. Who's framework for action. Geneva: WHO.

WHO, 2008. Medium-term strategic plan 2008-2013 and programme budget 2008-2009. Geneva: WHO.

WHO, 2009a. Continuity and change: Implementing the third WHO Medicines Strategy 2008-2013. Geneva: WHO.

WHO, 2009b. Immunization safety. [online] Available at: http://www.who.int/immunization_safety/en/. [Accessed 20 September 2012]. 
WHO, 2011. First WHO Global Forum on Medical Devices: context, outcomes and future actions. Geneva: WHO.

WHO \& UNICEF, 2006. GIVS: Global Immunization and Vaccine Strategy2006-2015. Geneva: WHO.

WIPO, 2012. WIPO Re:Search. [online] Available at: http://www.wipo.int/research/en/. [Accessed on 10 October 2012.]

WTO, 2001. Ministerial Conference, Fourth Session, Doha, 9 - 14 November 2001, Declaration on the Trips Agreement and Public Health. WTO Doc.

$\mathrm{WT} / \mathrm{MIN}(01) / \mathrm{DEC} / \mathrm{W} / 2$.

WTO, 2003. General Council Implementation of paragraph 6 of the Doha Declaration on the TRIPS Agreement and public health. Decision of the General Council of 30 August 2003. WT/L/540 and Corr. 1.

Yamin, A.E., 2003. Not Just a Tragedy: Access to Medications As A Right Under International Law. Boston University International Law Journal, 21, pp.325-71.

Yamin, A.E., and Parra-Vera, O., 2009. How do courts set health policy? The case of the Colombian Constitutional Court. PLOS Medicine, 6(2), pp.147-50.

Yu, P.K., 2008. Access to medicines, BRICS alliance, and collective action. American Journal of Law and Medicine 34, pp.345-94. 